\title{
CHARACTERIZATION OF MYCOPLASMA PENETRANS AND MYCOPLASMA FERMENTANS IMMUNODOMINANT PROTEINS
}

\author{
Juliana Bruder; Renata Cristina Godry; Kioko Takei; Regina Ayr Florio da Cunha*
}

Departamento de Análises Clínicas, Faculdade de Ciências Farmacêuticas da Universidade de São Paulo, São Paulo, Brasil

Submitted: October 22, 2004; Returned to authors for corrections: February 14, 2005; Approved: June 15, 2005

\begin{abstract}
Mycoplasmas are a heterogeneous group of the smallest organisms capable of self replication and are known to cause many detrimental diseases in both animals and humans. These wall-less prokaryotes are enveloped by a lipoprotein membrane and their small genomes are sufficient to synthesize molecules required for growth and self-replication. Among sixteen species isolated from humans, Mycoplasma pneumoniae, an agent of primary atypical pneumonia, and the urogenital tract species Mycoplasma hominis, Ureaplasma urealyticum and Ureaplasma parvum have been confirmed to be pathogenic. Mycoplasma penetrans and Mycoplasma fermentans, which are species associated with HIV, have been investigated mainly in research laboratories. In this study we have characterized lipid-associated membrane proteins (LAMP) of Mycoplasma penetrans and Mycoplasma fermentans, in view of the importance of mycoplasmas in human diseases and the peculiar antigenic variation observed in these species. To characterize proteins with possible diagnostic value, we used ELISA and Western blot in sera of pregnant women whose cervical samples were positive for these species of mycoplasmas when tested by PCR. ELISA showed IgG anti-LAMP-M. fermentans antibodies to be present in $57.5 \%$ of cases and IgM antibodies to be present in $74.5 \%$ of cases. The three samples that were PCR positive for M. penetrans showed IgG anti-LAMP-M. penetrans antibodies, and one sample was positive for IgM. No IgA antibodies against either species were detected in any of the samples. LAMP analysis by Western blot revealed the 35, 38, 42, 61 and $103 \mathrm{kDa}$ proteins of $M$. penetrans and the 29, 38, 41, 61, 78 and 95 $\mathrm{kDa}$ proteins of $M$. fermentans. Among these, will be considered $\mathrm{p} 35$ to $M$. penetrans and $29 \mathrm{kDa}$ protein to $M$. fermentans, the main immunoreactive proteins and therefore useful markers for further laboratory diagnosis.
\end{abstract}

Key words: Mycoplasma penetrans, Mycoplasma fermentans, LAMP-proteins, ELISA, Western blot

\section{INTRODUCTION}

In spite of the outstanding progress made in our understanding of the nature of mycoplasmas, their taxonomic position and their relationship with other organisms, they still represent an enigma for microbiologists because some mechanisms of pathogenicity are still unknown. Mycoplasma cell is only enveloped by a lipoprotein membrane and the genome, despite its diminutive size, is sufficient for selfreplication.
Adherence and intense antigenic variation allow mycoplasmas to escape efficiently from host immune responses, thus allowing chronic infectious diseases to become established $(11,16,18)$. More than 170 mycoplasma species live as parasites on human and animal cellular surfaces by sticking to and colonizing the epithelial coating of the respiratory and urogenital tracts, but rarely invade adjacent tissues (11). The pathogenicity of mycoplasmas is therefore related, among other things, to the absence of the cell wall. The inner contact is possible via adhesion proteins and the high-frequency antigenic variation

*Corresponding Author. Mailing address: Departamento de Análises Clínicas, Faculdade de Ciências Farmacêuticas, Universidade de São Paulo. Av. Prof. Lineu Prestes, 580, bloco 17, Cidade Unviersitária. 05508-900, São Paulo, SP, Brasil. Tel.: (+5511) 3091-3638/3662, Fax: (+5511) 3813-2197. Email: reca@usp.br; rafc22@bol.com.br 
represented by the lipoprotein membrane (21). Mycoplasma fermentans and Mycoplasma penetrans species isolated from urine and blood of HIV infected patients have been associated with the AIDS progression as possible co-factors in the development of this disease. Mycoplasma fermentans was isolated for the first time from the urogenital tract and, later, from other body parts and fluids such as: bone marrow of leukemic patients; the trachea, urine and blood of HIV carriers; saliva of healthy subjects; and synovial liquid of patients with rheumatoid arthritis $(9,10,16,22)$. The significant detection rate of these microorganisms among healthy subjects and among patients remains a paradox. The lipoprotein of $M$. fermentans is abundant in the surface of the membrane and shows strong antigenicity and immunogenicity $(24,28)$. The antigenic variation in these species is clearly demonstrated by the presence of p150, p 95, p78, p61, p48, p43, p41, p38 and p29 proteins. Protein p29 is the main lipid-associated membrane protein and expresses a high frequency of phase variation $(15,25)$.

M. penetrans, although described in 1992, is the most recent species of Mollicutes isolated in humans. Properties of adherence, hemadsorption, cytoadsorption and invasion of mammalian epithelial cells have been described. The last property is responsible for its name $(6,14,23)$. Analysis of $M$. penetrans isolated from the urine of HIV homosexual subjects $(13,14)$ has shown that it may act as a co-factor of the virus, accelerating the evolution of this retroviral disease $(1,2,8) . M$. penetrans adhesion to the host cell is related to the $35,38,61$ $\mathrm{kDa}$ lipid-associated membrane proteins (LAMP) and to the $103 \mathrm{kDa}$ proteins. Studies with sera of HIV positive patients showed p35 and p38 to be immunodominant proteins $(3,6,27)$. However, p35 and p38 was shown to be the specific lipoproteins for $M$. penetrans in Western blot with a high frequency of phase variation $(7,19,20)$. These lipoproteins and their adhesins act as potent immunogens, determining the nature, intensity and multiple specificity of the host immune response.

The studies of these microorganisms in other clinical conditions and in different populations are very important to know how widespread these infections are and if there is any association with other diseases. Standardization of ELISA using LAMP antigen and characterization of immunodominants proteins would be of great importance for this purpose. The aim of this work was to characterize some antigens in the Mycoplasma penetrans and Mycoplasma fermentans membranes for further laboratory diagnosis, in view of the importance of mycoplasmas in human diseases and the antigenic variation in the species.

\section{MATERIALS AND METHODS}

\section{Mycoplasma strains and culture methods}

M. penetrans GTU-54-6A1 was cultured in SP-4 medium at $37^{\circ} \mathrm{C}$ under aerobic conditions. M. fermentans ATCC 19989 was cultured in SP-4 medium at $37^{\circ} \mathrm{C}$ under anaerobic conditions. LAMP antigen preparation was as follows: Mycoplasma lipidassociated membrane proteins (LAMP) were obtained in accordance with the method described by Wang et al. (27). Briefly, $500 \mathrm{~mL}$ of broth cultures were centrifuged at $12,000 \mathrm{x} \mathrm{g}$ for $60 \mathrm{~min}$ at $4^{\circ} \mathrm{C}$. Mycoplasma pellets were washed three times in phosphate-buffered saline (PBS) $\mathrm{pH} 7.4$ containing timerosal and were re-suspended in $45 \mathrm{~mL}$ of Tris- $\mathrm{HCl} 50 \mathrm{mM}, \mathrm{NaCl} 150$ mM, EDTA $1 \mathrm{mM}$, pH 8.0, followed by addition of $5 \mathrm{~mL}$ of $10 \%$ Triton X-114 solution. This mixture was submitted to ultrasonic disruption at three cycles/min. After 90 minutes the solution was centrifuged at $20,000 \mathrm{x}$ for $30 \mathrm{~min}$ at $4^{\circ} \mathrm{C}$. The supernatant was submitted to partition phase by incubation for $5 \mathrm{~min}$ at $30^{\circ} \mathrm{C}$ followed by centrifugation at 2,500 x $\mathrm{g}$ for $5 \mathrm{~min}$ at room temperature. Detergent phase containing LAMP was collected and submitted to another partition phase as previously described. This detergent phase was named LAMP, and stored at $-20^{\circ} \mathrm{C}$ after the addition of phenylmethylsulphonylfluoride (PMSF). Characterization of LAMP was carried out by analysis of protein profile using sodium dodecyl sulfate polyacrilamide gel electrophoresis (SDS-PAGE) in 7-15\% gradient gels by the Laemmli (12) method and by visualization of the proteins pattern using Coomassie Brilliant Blue staining (26).

\section{Patient samples}

Serum samples were obtained from 50 pregnant women receiving routine prenatal care at the Gynecology and Obstetrics Department of the Hospital do Servidor Público do Estado de São Paulo, whose cervical samples were PCR positive for $M$. penetrans or $M$. fermentans. Forty seven cervical samples obtained from these 50 patients were PCR-positive for $M$. fermentans and three for $M$. penetrans. Serum samples were stored at $-20^{\circ} \mathrm{C}$ until used.

\section{Control group}

The thirty serum samples in the control group were obtained from healthy male blood donors at the blood bank of the Hospital do Servidor Público do Estado de São Paulo. The results obtained were used for calculating cut-off value.

\section{Serological tests}

ELISA: Polystyrene plates (MaxiSorp F, NUNC, Denmark) were coated with $100 \mu \mathrm{L}$ of LAMP containing $1.5 \mu \mathrm{g}$ of protein per well, diluted in TBC buffer $\left(0.015 \mathrm{M} \mathrm{Na}_{2} \mathrm{CO}_{3}\right.$ and $0.04 \mathrm{M}$ $\mathrm{NaHCO}_{3}$ ) and incubated for 18 hours at $37^{\circ} \mathrm{C}$. After incubation, the plates were washed four times with solution $\mathrm{A}(\mathrm{PBS}, \mathrm{pH} 7.4$, plus $0.05 \%$ Tween 20 ) and overcoated with $5 \%$ powdered skimmed milk (Molico, Nestlé) in solution A for $30 \mathrm{~min}$. at $37^{\circ} \mathrm{C}$. After one washing step, the sera were diluted 1:100 in solution A plus $1 \%$ powdered skimmed milk and incubated for $120 \mathrm{~min}$ at $37^{\circ} \mathrm{C}$. The plates were washed four times and peroxidaseconjugated anti- $\gamma,-\mu$, or $-\alpha$ chains (Sigma Chemical Co., St. 
Louis, MO, USA) were added to detect IgG, IgM or IgA antibodies respectively. After $2 \mathrm{~h}$ of incubation at $37^{\circ} \mathrm{C}$, the color was developed by addition of $2.0 \mathrm{mg}$ of ortho-phenylenediamine (Sigma Chemical Company, St. Louis, MO, USA) and $20 \mu \mathrm{L}$ of hydrogen peroxide in $20 \mathrm{~mL}$ of $0.2 \mathrm{M}$ citrate/phosphate buffer. The enzymatic reaction was stopped by addition of $100 \mu \mathrm{L} /$ well of $4 \mathrm{~N}$ sulfuric acid. The absorbance at $492 \mathrm{~nm}$ was measured in a plate reader (Spectra I - 5082).

Samples with absorbance equal to or higher than the mean of the control group plus two standard deviations (SDs) for $\operatorname{IgG}, \operatorname{IgM}$ and $\operatorname{Ig}$ A were considered positive.

\section{Western blot}

Western blot was performed to identify immunoreactive proteins and to determine cross-reactive proteins of $M$. penetrans and $M$. fermentans in serum samples of pregnant women.

Polyvinylidene fluoride (PVDF) $0.22 \mathrm{~nm}$ membranes containing mycoplasma LAMP fractions that were separated by $10 \%$ SDSPAGE and electroblotted were cut into strips of about $3 \mathrm{~mm}$. The strips were washed under shaking conditions in PBS $\mathrm{pH} 7.4$ containing $0.05 \%$ Tween 20 and blocked with 5\% skimmed milk (Molico, Nestlé) in PBS pH 7.4 for $2 \mathrm{~h}$. After the washing step, the sera were diluted at 1:50 in 1\% powdered skimmed milk in $\mathrm{PBS} \mathrm{pH}$ 7.4. After $18 \mathrm{~h}$ of incubation at $4^{\circ} \mathrm{C}$ and three washes, the strips were incubated with specific conjugates: peroxidase-labeled goat anti-human-IgG, anti-human-IgM and anti-human-IgA antibodies diluted respectively at 1:8,000, 1:4,000 and 1:4,000. After $2 \mathrm{~h}$ of incubation at $37^{\circ} \mathrm{C}$ and the washing steps, DAB/ $\mathrm{H}_{2} \mathrm{O}_{2}(5 \mathrm{mg}$ diaminobenzidine in $30 \mathrm{ml} \mathrm{PBS} \mathrm{pH} 7.4$ and $150 \mathrm{~mL} 30 \% \mathrm{H}_{2} \mathrm{O}_{2}$ ) was added. After 15 mins the strips were washed ten times with distilled water and analyzed by visual inspection.

\section{RESULTS}

Characterization of the LAMP fractions of the species studied by SDS-PAGE revealed a proteins profile for Mycoplasma penetrans in which the two major antigenic proteins, p35 and p38 were prominent. We also observed 42, 61 and $103 \mathrm{kDa}$ proteins. The profile of the LAMP fraction of Mycoplasma fermentans revealed 29, 38, 41, 61, 78, 95 and 150 $\mathrm{kDa}$ proteins. The bands p35 and p29 identified in this study are those referred in the literature as being specific for $M$. penetrans and M. fermentans (7,15,27) (Fig. 1).

Samples were considered ELISA positive when optical density was equal to or higher than the established cut-off values: $0.23(\mathrm{IgG}), 0.28(\mathrm{IgM})$ and $0.20(\mathrm{IgA})$ for M. penetrans, and $0.22(\mathrm{IgG}), 0.30(\mathrm{IgM})$ and $0.22(\mathrm{IgA})$ for $M$. fermentans. These cut-off values were obtained from the results of the control group sera.

IgG and IgM antibodies for M. penetrans were detected in 3 and 1 respectively of 3 sera samples of pregnant women, using

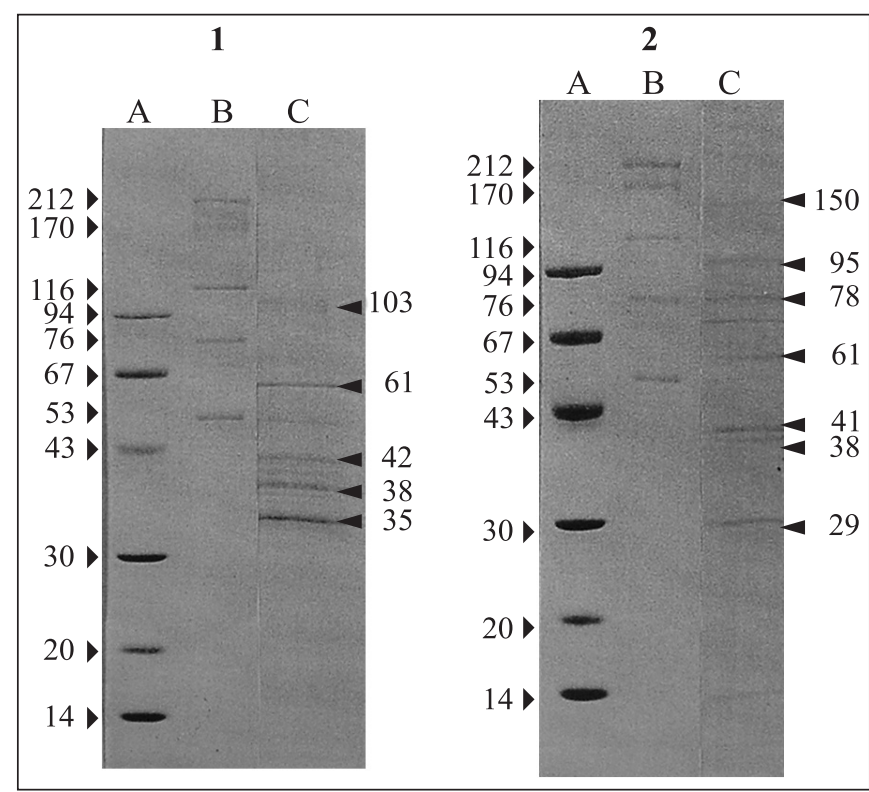

Figure 1. Electrophoretic protein profile in SDS-PAGE 7 to $15 \%$ of LAMP preparations of Mycoplasma penetrans (1) and Mycoplasma fermentans (2) with Coomassie Brilliant Blue (C) stain. $1 \mathrm{~A}$ and $2 \mathrm{~A}$ indicate low molecular weight-calibrator; $1 \mathrm{~B}$ and $2 \mathrm{~B}$ indicate high molecular weight-calibrator. The arrows indicate the 35, 38, 42, 61 and $103 \mathrm{kDa}$ proteins for Mycoplasma penetrans (1) and the 29,38, 41, 61, 78, 95 and $150 \mathrm{kDa}$ proteins for Mycoplasma fermentans (2).

ELISA; for $M$. fermentans the respective figures were $57.5 \%$ (27/47) and 74.5\% (35/47). IgA antibodies were not found in either case.

Western blot for M. penetrans showed $\operatorname{IgG}$ antibody reactivity in 3 of samples for 35,38 and $61 \mathrm{kDa}$ proteins and in 2 of samples for 42 and $103 \mathrm{kDa}$ proteins, others proteins were observed but they were not characteristic for the specie. $\operatorname{IgM}$ antibody reactivity showed positive results for 38 and $61 \mathrm{kDa}$ proteins in all 3 samples and 35 and $42 \mathrm{kDa}$ proteins in 2 samples. Specific $M$. penetrans IgA antibodies were not found.

Western blot for M. fermentans showed IgG antibody reactivity characteristic of specie against 29, 38, 41, 61, 78 and $95 \mathrm{kDa}$ proteins, with a frequency of $32.0 \%(15 / 47), 25.5 \%(12 /$ 47), 53.2\% (25/47), 19.1\% (9/47), 51.1\% (24/47) and 17.0\% (8/ 47) respectively. For the same proteins $\operatorname{IgM}$ reactivity was detected in $36.2 \%$ (17/47), $40.5 \%$ (19/47), $42.6 \%$ (20/47), $19.1 \%$ (9/47), 27.7\% (13/47) and 2.1\% (1/47) of samples respectively. Although IgA antibodies were not detected by ELISA, using Western blot we identified a weak reactivity to some proteins no characteristic of the specie (Fig. 2).

The results obtained by ELISA and Western blot assays are shown in Table 1. 


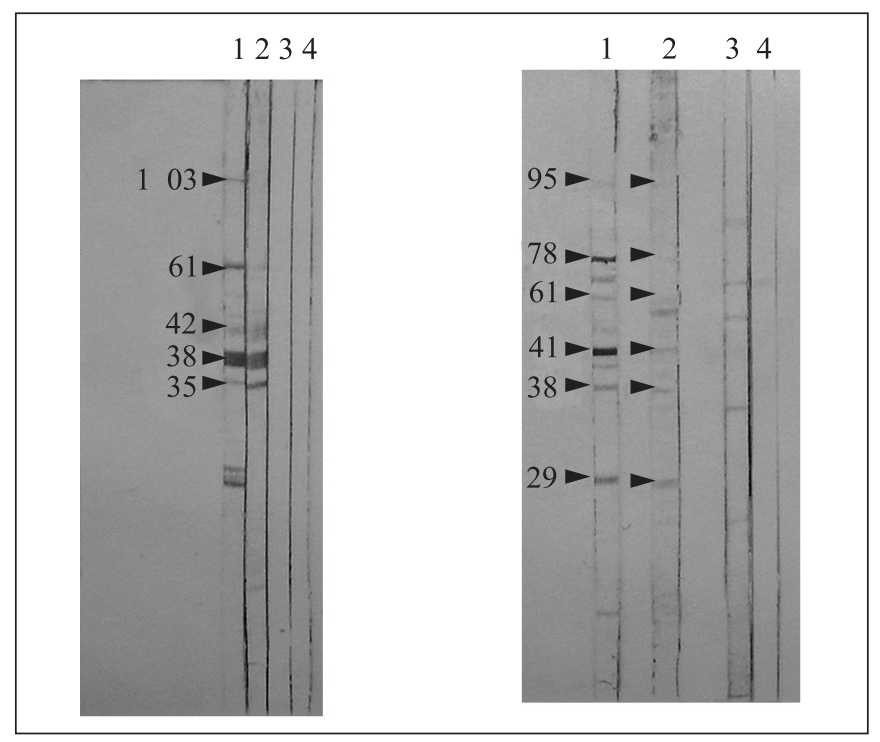

Figure 2. Western blot: reactivity profile of sera of pregnant women for $M$. penetrans (A) and $M$. fermentans (B) proteins. Strips 1, 2, 3 and 4 show the $\operatorname{IgG}, \operatorname{IgM}$ and $\operatorname{IgA}$ bands and negative serum control respectively. The 35, 38, 42, 61 and 103 kDa proteins of $M$. penetrans and the 29, 38, 41, 61, 78 and 95 kDa proteins of $M$. fermentans were detected.

Table 1. ELISA and Western blot results for sera of pregnant women (cervical samples PCR positive) using $M$. penetrans and $M$. fermentans LAMP fractions.

\begin{tabular}{|c|c|c|c|}
\hline \multirow{2}{*}{$\begin{array}{c}\text { Mycoplasma } \\
\text { species }\end{array}$} & \multirow{2}{*}{$\begin{array}{c}\text { Antibodies } \\
\text { Isotypes }\end{array}$} & \multicolumn{2}{|c|}{ Sera of pregnant women } \\
\hline & & $\begin{array}{c}\text { ELISA } \\
\mathrm{p} / \mathrm{n}(\%)\end{array}$ & $\begin{array}{l}\text { Western blot } \\
(\mathrm{kDa})\end{array}$ \\
\hline \multirow{3}{*}{ M. penetrans } & IgG & $3 / 3$ & $103,61,38,35$ \\
\hline & $\operatorname{IgM}$ & $1 / 3$ & $61,38,35$ \\
\hline & $\operatorname{Ig} \mathrm{A}$ & $\mathrm{nd}^{*}$ & $\mathrm{nd}^{*}$ \\
\hline \multirow{3}{*}{ M. fermentans } & IgG & $27 / 47(57.5)$ & $95,78,61,48,41,29$ \\
\hline & $\operatorname{IgM}$ & $35 / 47(74.5)$ & $95,78,61,48,41,29$ \\
\hline & $\operatorname{Ig} \mathrm{A}$ & $\mathrm{nd}^{*}$ & $\mathrm{nd} * *$ \\
\hline
\end{tabular}

nd*: not detected; nd**: specific bands not detected; $\mathrm{p}=$ samples positive by ELISA; $n=$ total number of samples.

A cross-reactivity study was performed using Western blot in sera of pregnant women whose cervical samples were PCR positive for $M$. penetrans and $M$. fermentans. We assayed $M$. penetrans positive sera versus LAMP of $M$. fermentans, and $M$. fermentans positive sera versus LAMP of $M$. penetrans. Two cross-reactive bands were observed: one for the $38 \mathrm{kDa}$ protein and one for the $61 \mathrm{kDa}$ protein.

\section{DISCUSSION}

The improvements in diagnosis arising from the use of molecular technology have resulted in the discovery of new species of pathogens which were formerly recognized as commensal organisms, and in the introduction of new concepts of mycoplasma diseases. Although the role of mycoplasmas in the pathogenesis of some human diseases still remains controversial, it has been suggested that these microorganisms contribute significantly as co-factors in disease progression.

The prevalence of mycoplasma infection in our country is not well known, mainly for emergent species such as $M$. penetrans and $M$. fermentans. Some serologic studies were carried out by Cordova et al., (4), who has investigated sera from $106 \mathrm{HIV}$ infected patients by ELISA, presented positivity of $25.5 \%, 9.1 \%$ and $15.1 \%$ respectively for $\operatorname{IgG}, \operatorname{IgM}$ and $\operatorname{IgA}$ anti-M. penetrans. They found also in 110 sexually transmitted disease (DST) anti-M. penetrans by ELISA 17.3\%, 9.1\% and $17.3 \%$ respectively for $\operatorname{IgG}, \operatorname{IgM}$ and $\operatorname{IgA}$.

Serological tests are a very practical tool to assess the prevalence of mycoplasma species and the distribution of these microorganisms in different populations and in different clinical conditions. However the presence of antigens shared by different species of mycoplasmas interferes in the specificity of serological tests and it may become not useful for diagnostic purposes.

ELISA using LAMP fraction antigen was assayed in sera of pregnant women really infected by $M$. penetrans or by $M$. fermentans to investigate antibody response against these two mycoplasmas. However we observed a low sensitivity using this antigenic fraction. For diagnostic purpose is necessary to improved it.

We found IgG antibody positivity in all three samples obtained from $M$. penetrans infected patients and IgM in two samples. No IgA antibodies were detected.

Due to the small number of samples involved in this study we were not able to reach a definitive conclusion and a study with a larger number of patients would be recommended.

Western blot analysis of LAMP from $M$. penetrans revealed IgG reactivity for p35, p38, p42, p61 and p103. However only p35 is considered specific of the specie (6). IgM antibody reactivity was observed for $\mathrm{p} 38$, and p61 in three samples, and p35 and p42 in two samples.

Anti- $M$. fermentans antibodies were identified using ELISA in sera of pregnant women with a frequency of $57.5 \%$ for $\mathrm{IgG}$ antibodies and $74.5 \%$ for $\operatorname{IgM}$ antibodies. IgA antibodies were not observed.

Western-blot analysis of M. fermentans showed 29, 38, 41, 61, 78 and $95 \mathrm{kDa}$ proteins. The $29 \mathrm{kDa}$ protein, which has high-frequency phase variation, was detected in the following frequencies: $31.9 \%$ and $36.2 \%$ for $\operatorname{IgG}$ and $\operatorname{IgM}$ antibodies respectively. Although this protein showed low frequency it 
is the most specific (25). A higher frequency observed was for $41 \mathrm{kDa}$ protein, although this is not referred to be specific of specie.

\section{Specific reactivity for species}

Analysis of Western blot profile of LAMP fraction allowed to identify some specie specific lipoproteins which showed strong immunoreactivity and some lipoproteins with crossreactivity.

Proteins of 35 and $38 \mathrm{kDa}$, the two main lipoproteins used by $M$. penetrans to penetrate into the host cell $(3,7)$, are the most abundant in mycoplasma cellular surface had have highfrequency phase variation (17). Our results showed a strong immunoreactivity these two proteins and the specie specificity of $35 \mathrm{kDa}$ lipoprotein as previously found by Ferris et al., (5).

Furthermore, Wang et al., (27) described two 61 and $103 \mathrm{kDa}$ proteins in sera of HIV patients, which were not identified in sera of HIV-negative patients. In our study, however, these two proteins were identified in sera of pregnant women, indicating a possible presence in general population.

Like other species of mycoplasma, Mycoplasma fermentans presents proteins that express phase variation. Our results revealed the presence of 29,38, 41, 61, 78, and $95 \mathrm{kDa}$ proteins, corroborating the results described by Theiss et al. (24).

Cross-reactivity profile: anti- $M$. fermentans antibodies revealed cross-reactivity in sera of pregnant women for p38 and p61 of M. penetrans. This enabled us to consider p29 as specific to $M$. fermentans and $\mathrm{p} 35$ as specific to $M$. penetrans.

Our work consisted of a study into the characterization of the species Mycoplasma penetrans and Mycoplasma fermentans. The study revealed the presence of proteins already mentioned in the international literature, but also revealed the presence of other strongly reactive proteins.

\section{ACKNOWLEDGEMENTS}

We wish to thank FAPESP for supporting this work (Process $\mathrm{n}^{\circ}$ 99/00821-5).

\section{RESUMO}

\section{Caracterização de proteinas imunodominantes de Mycoplasma penetrans e Mycoplasma fermentans}

Micoplasmas são procariotos diminutos, desprovidos de parede celular e envoltos por uma membrana lipoproteica cujo pequeno genoma sintetiza a maioria das moléculas necessárias para crescimento e replicação. Dentre as dezesseis espécies isoladas do homem, Mycoplasma pneumoniae, agente causador da pneumonia atípica primária, e as espécies do trato urogenital como Mycoplasma hominis, Ureaplasma urealyticum e Ureaplasma parvum têm definido seu papel patogênico. $M$. penetrans e $M$. fermentans, espécies associadas ao HIV, têm sido investigadas principalmente em laboratórios de pesquisa. Considerando a importância dos micoplasmas nas doenças humanas e a peculiar variação antigênica observada em tais espécies, foram caracterizadas, neste estudo, as lipoproteínas associadas a membranas (LAMP) de Mycoplasma penetrans e Mycoplasma fermentans. Para definir peptídeos com possível valor diagnóstico, empregamos as técnicas de ELISA e de Western blot usando soros de gestantes cujas amostras cervicais foram positivas por PCR. Por meio do ELISA foram observados anticorpos IgG anti-LAMP-M. fermentans em 57,5\% e IgM em 74,5\% das amostras. As três amostras PCR positivas para $M$. penetrans apresentaram anticorpos IgG anti-LAMP- $M$. penetrans e uma amostra positiva para $\operatorname{IgM}$. IgA não foi detectada em nenhuma das espécies. A análise da LAMP, por Western blot, revelou como principais proteinas imunoreativas: 35, 38, 42, 61 and $103 \mathrm{kDa}$ para M. penetrans e 29, 38, 41, 61, 78 and $95 \mathrm{kDa}$ de $M$. fermentans. Dentre estas podemos considerar p35 específica para $M$. penetrans e p29, M. fermentans.Tais proteinas são promissoras como marcadores em diagnóstico.

Palavras-chave: LAMP-peptídeos, Mycoplasma penetrans, Mycoplasma fermentans, ELISA, Western blot

\section{REFERENCES}

1. Blanchard, A.; Montaigner, L. AIDS-associated mycoplasmas. Annu. Rev. Microbiol., 48, 687-712, 1994.

2. Blanchard, A.; Montagnier, L.; Gougeon, M. L. Influence of microbial infections on the progression of HIV disease. Trends Microbiol., 5, 326-331, 1997.

3. Brenner, C.; Neyrolles, O.; Blanchard, A. Mycoplasmas and HIV infection: from epidemiology to their interaction with immune cells Front. Biosci., 1, 42-54, 1996.

4. Cordova, C.M.M.; Takei. K.; Rosenthal, C.; Vaz, A.J.; Cunha, R.A.F. Evaluation of $\mathrm{IgG}, \mathrm{IgM}$, and IgA antibodies to Mycoplasma penetrans detected by ELISA and immunoblot in HIV-1-infected and STD patients, in Sao Paulo, Brazil. Microbes Infect., 1, 1095, 1999.

5. Ferris, S.; Watson, H.L.; Neyrolles, O.; Montagnier, L.; Blanchard, A. Characterization of a major Mycoplasma penetrans lipoprotein and of its gene. FEMS Microbiol. Lett., 130, 313-320, 1995.

6. Girón, J.A.; Lange, M.; Baseman, J.B. Adherence, fibronectin binding, and induction of cytoskeleton reorganization in cultured human cells by Mycoplasma penetrans. Infect. Immun., 64, 197-208, 1996.

7. Grau, O.; Slizewicz, B.; Tuppin, P.; Launay, V.; Bourgois, E.; Sagot, N.; Moynier, M.; Lafeulilade, A.; Bachelez, H.; Clauvel, J.-P.; Blanchard, A.; Bahraoui, E.; Montagnier, L. Association of Mycoplasma penetrans with human immunodeficiency virus infection. J. Infect. Dis., 172, 672-681, 1995.

8. Grau, O.; Tuppin, P.; Slizewicz, B.; Launay, V.; Goujard, C.; Bahraoui, E.; Delfraisy, J.F.; Montagnier, L. A longitudinal study of seroreactivity against Mycoplasma penetrans in HIV-infected homosexual men: association with disease progression. AIDS Res. Hum. Retroviruses., 14, 661-667, 1998.

9. Johnson S.; Sidebottom, D.; Bruckner, F.; Collins, D. Identification of Mycoplasma fermentans in synovial fluid samples from arthritis patients with inflammatory disease. J. Clin. Microbiol., 38, 90-93, 2000. 
10. Katseni, V.L.; Gilroy, C.B.; Ryait, B.K.; Ariyoshi, K.; Bieniaz, P.D.; Weber, J.N.; Taylor-Robson, D. Mycoplasma fermentans in individuals seropositive and seronegative for HIV-1. Lancet., 341, 271-273, 1993.

11. Ladefoged, S.A. Molecular dissection of Mycoplasma hominis. Acta Path. Microbiol. Scand., 97, 1-45, 2000.

12. Laemmli, U.K. Cleavage of structural proteins during the assembly of the head of bacteriophage T4. Nature. 22, 680-685, 1970.

13. Lo, S.C.; Hayes, M.M.; Wang, R. Y.-H; Pierce, P.; Kotani, H.; Shih, J.W.-K. Newly discovered mycoplasma isolated from patients infected with HIV. Lancet., 338, 1415-1418, 1991.

14. Lo, S.C.; Hayes, M.M.; Tully, J.G.; Wang, R.Y.-H.; Kotani, H. Mycoplasma penetrans sp. nov., from the urogenital tract of patients with AIDS. Int. J. System. Bacteriol., 42, 375-364, 1992.

15. Matsumoto. M.; Nishiguchi, M.; Kikkawa, S.; Nishimura, H.; Nagasawa, S.; Seya, T. Structural and functional properties of complement activating protein M161 Ag, a Mycoplasma fermentans gene production by human monocytes. J. Biol. Chem., 273, 1240712414, 1998.

16. Murphy, W.H.; Bullis, C.; Dabich, L.; Heyn, R.; Zarafonetis, C.J.D. Isolation of mycoplasma from leukemic and non-leukemic patients. J. Nat. Cancer Inst., 45, 243-251, 1970.

17. Neyrolles, O.; Eliane, J.-P.; Ferris, S.; Prevost, M.-C.; Sasaki, T.; Montagnier, L.; Blanchar, A. Antigenic characterization and cytolocalization of P35, the major Mycoplasma penetrans antigen. Microbiology, 145, 343-355, 1999.

18. Razin, S.- Mycoplasma taxonomy and ecology. In: Maniloff, J.; Mcelhaney, L.R.; Finch, L.R.; Basenab, J.B. (eds). Mycoplasmas: Molecular Biology and Pathogenesis. American Society for Microbiology, Washington, 1992, p.3-22.
19. Razin, S.; Barash, V. Solubilization of Mycoplasma membranes by the nonionic detergent Triton X-100. FEBS Lett., 3, 217-220, 1969.

20. Razin, S.; Argaman, M.; Avigan, J. Chemical composition of mycoplasma cells and membranes. J. Gen. Microbiol., 33, 477-487, 1963.

21. Razin, S.; Yogev, D.; Naot, Y. Molecular biology and pathogenicity of mycoplasmas. Microbiol. Molec. Biol. Rev., 62, 1094-1156, 1998.

22. Shibata, K.; Kaga, M.; Kudo, M. Detection of Mycoplasma fermentans in saliva sampled from infants, preschool and school children, adolescents and adults by a polymerase chain reaction-based assay. Microbiol Immunol., 43, 521, 1999.

23. Stadtländer, C.T.; Watson, H.L.; Simecka, J.W.; Cassel, G.H. Cytopathogenicity of Mycoplasma fermentans (including strain incognitus). Clin. Infect. Dis., 17, 289-301, 1993.

24. Theiss, P.M.; Kim, M.F.; Wise, K.S. Differential protein expression and surface presentation generate high-frequency antigenic variation in Mycoplasma fermentans. Infec. Immun., 61, 5126-5128, 1993.

25. Theiss, P.; Karpas, A.; Wise, K.S. Antigenic topology of the P29 surface lipoprotein of Mycoplasma fermentans: differential display of epitopes results in high-frequency phase variation. Infect. Immun., 64, 1800-1809, 1996.

26. Tsai, C-.M.; Frasch, C.E. A sensitive silver stain for detecting lipopolysaccharides in polyacrilamide gels. Analyt. Biochem., 119, 115-119, 1982.

27. Wang, R.Y.; Shih, J.W.; Grandinetti, T.; Pierce, P.P.; Hayes, M.M.; Wear, D.J.; Alter, H.J.; Lo. S.-C. High frequency of antibodies to Mycoplasma penetrans in HIV-infected patients. Lancet, 340, 13121316, 1992

28. Wise, K.S.; Kim, M.F.; Theiss, P.M.; Lo, S.C. A family of strainvariant surface lipoproteins of Mycoplasma fermentans. Infec. Immun., 61, 3327-3333, 1993. 